\title{
DƯSLEDKY IMPLEMENTACE SMĚRNICE MiFID PRO JEDNÁNÍ OBCHODNÍKŮ S CENNÝMI PAPÍRY VE VZTAHU KE KLIENTŮM
}

\author{
Lucie Meixnerová
}

\section{Klíčová slova:}

Směrnice o trzích finančních nástrojů - nazývána MiFID, neprofesionální klient, obchodník s cennými papíry, investiční profil, test vhodnosti, test přiměřenosti

\section{Key words:}

The Markets in Financial Instruments Directive or MiFID, non-professional client, securities trader, investment profile, suitability test, appropriateness test

\begin{abstract}
Abstrakt
Směrnice o trzích finančních instrumentů (MiFID) vstoupila v platnost v listopadu 2007 a rozšiřuje rozsah služeb i finančních instrumentů, na které se předtím vztahovala směrnice o investičních službách (ISD). Tato směrnice nastavuje nové postupy, procesy a pravidla jednání ve vztahu k zákazníkům a kontrolní opatření při každodenním jednání obchodníka s cennými papíry se zákazníkem. Tato pravidla se liší v závislosti na klasifikaci zákazníka (drobný klient, profesionální klient a způsobilá protistrana) a definuje základní požadavky na poskytování informací a povinnosti obchodníků s cennými papíry vůči zákazníkům a při správě cizího majetku. Cílem příspěvku je popsat proces prodeje investic drobným klientům včetně důležitých povinností při poskytování příslušných investičních služeb.
\end{abstract}

\begin{abstract}
The Markets in Financial Instruments Directive (MiFID), was come into force in November 2007 and broadens the scope of both services and financial instruments covered previously by the Investment Services Directive (ISD). MiFID sets out new policies, processes and the conduct of business rules with clients and controls around how an investment firm works on a daily basis with clients. These rules are differ depending on the classification of the clients themselves (retail client, professional client or eligible counterparty). MiFID sets out the basic information requirements and fiduciary duties of investment firms towars their customers. The objective of this document is to describe the Investments Sales process for nonprofessional clients including of providing respective investment services to such clients.
\end{abstract}

\section{Úvod}

Česká republika stejně jako každý členský stát EU (Evropská unie), zavedla v roce 2007 do svého právního řádu rámcovou směrnici MiFID. Směrnice MiFID a jí prováděcí směrnice se týká hlavně oblasti jako jsou zásady pro poskytování investičních služeb zákazníkům, test běžného investora, tř́dění zákazníků pro přístup poskytovatele investičních služeb, cíle poskytování informací zákazníkům, časový předpis pro poskytování informací zákazníkům, aktualizace informací poskytovaných zákazníkủm a zajištění „,nejlepších“ podmínek pro provedení pokynů. Smyslem směrnice je tedy zlepšení transparentnosti nabízených služeb, podpora konkurenčního prostředí a zvýšení ochrany investorů. Směrnice má přinést zlepšení a nové př́íležitosti včetně toho, že investoři mohou očekávat levnější a kvalitnější služby.

Cílem tohoto příspěvku je popsat proces prodeje investičních produktů u klientů (klienti z řad obyvatelstva, klasifikováni jako neprofesionální klienti) a poskytnout jim podrobné pokyny týkající se obchodování a jiných důležitých povinností při poskytování příslušných investičních služeb. Proces prodeje investic definuje proces nákupu a prodeje investičního 
nástroje, investiční poradenství a obhospodařování zákaznického majetku. Zahrnuje tedy nákup a prodej investičních cenných papírů (zejména akcie a dluhopisy), cenných papírů kolektivního investování, nástroje peněžního trhu a všechny druhy derivátů (včetně strukturovaných produkti̊), které se vztahují na obchodníky s cennými papíry působící na území České republiky. Proces prodeje investic popisuje běžný postup př́i prodeji investičních produktů a tento postup znamená, že každý investiční nástroj má svůj vlastní rizikový profil, který by měl být porovnán s rizikovým profilem zákazníka (klienta).

Z pohledu zákazníka jsou změny, které se na ně vztahují komplexní a navzájem provázané a můžeme je rozčlenit do dvou skupin:

1) změny související s tržní strukturou (obchodování s cennými papíry),

2) změny související s pravidly pro jednání se zákazníky za nejlepších podmínek tzv. pravidlo Best Execution.

\section{Evropská směrnice o trzích finančních nástrojů}

V souladu s novou směrnici o trzích finančních nástrojů se regulace v oblasti investičních služeb od 1. prosince 2008 vztahuje na dodržování práv a povinností při poskytování investičních poradenských služeb subjektů podnikajících na kapitálovém trhu. Vymezení subjektů na kapitálovém trhu upravuje zákon č. 256/2004 Sb., o podnikání na kapitálovém trhu. Mezi nejvýznamnější subjekty působící na kapitálovém trhu patří obchodník s cennými papíry (obchodník), který je právnickou osobou, která poskytuje hlavní a doplňkové služby na základě povolení České národní banky a povolení k činnosti obchodníka uděluje pouze akciové společnosti nebo společnosti s ručením omezeným. Obchodník s cennými papíry, který není bankou, se řídí zákonem č. 256/2004 Sb., o podnikání na kapitálovém trhu. Postavení obchodníka s cennými papíry, který je bankou, jeho postavení upravuje zákon o podnikání na kapitálovém trhu a také zákon upravující činnosti bank. Zákon dále definuje investičního zprostředkovatele, tato osoba není oprávněna poskytovat jinou hlavní investiční službu než přijímání a předávání pokynů týkajících se investičních nástrojů nebo investiční poradenství týkajících se investičních nástrojů, nepřijímá peněžní prostředky nebo investiční nástroje zákazníků, ale pokyny pouze předává. Zákon dále definuje vázaného zástupce, který je fyzickou nebo právnickou osobou, která je oprávněna na základě písemné smlouvy se zastoupeným jménem obchodníka zařídit, popř. uzavírat obchody týkající se hlavní investiční služby nebo poskytovat popř. propagovat investiční službu, tak jak stanoví zákon č. 256/2004 Sb., o podnikání na kapitálovém trhu. Bližší požadavky na definování těchto a dalších subjektů, jejich předmětů činností a povinností je stanoveno v zákoně o podnikání na kapitálovém trhu. Tento zákon také rozlišuje hlavní investiční služby a doplňkové investiční služby, které nesmí nikdo poskytovat bez povolení vydaných Českou národní bankou, pokud tento zákon nebo jiný právní předpis nestanoví jinak.

Činnosti subjekti̊ působící na kapitálovém trhu se překrývají v rámci služeb investičního poradenství nebo správy aktiv, na něž se vztahuje směrnice MiFID a jsou dále v př́íspěvku podrobně rozebírány.

Směrnice MiFID upravuje podmínky podnikání na kapitálovém trhu, rozšiřuje rozsah regulovaných služeb a investičních nástrojů. Tato směrnice zavedla nové požadavky, které jsou obchodníci povinni přijmout a provádí významné změny regulačního rámce, které zohledňují nedávný vývoj v odvětví finančních služeb. Do své regulace zahrnuje například finanční deriváty, komoditní deriváty, kreditní deriváty nebo finanční kontrakty na vyrovnání rozdílů. Nově je zahrnuto také investiční poradenství a provozování vícestranných (alternativních) obchodních systémů (tzv. multilateral trading facilities). Tato směrnice 
stanovuje také požadavky na vnitřní kontrolní a řídící systémy, zejména v oblasti dodržování zákonných požadavků (compliance), interního auditu, řízení rizik, outsourcingu, informačních systémů a evidence. Jednou z klíčových oblastí, kterou MiFID zavádí je tzv. kategorizace zákazníků na profesionální a neprofesionální (retailové). Směrnice stanovuje, jak kategorizaci provádět a udává podrobná pravidla při hodnocení investičních služeb a investičních nástrojů vhodných pro klienta $\mathrm{v}$ dané kategorii. $\mathrm{K}$ významnému rozšîrení došlo také zejména $\mathrm{v}$ rámci úpravy režimu pro jednání se zákazníky. V této souvislosti klade MiFID na obchodníka poskytující investiční služby vyšší požadavky při zjišt’ování informací od zákazníků v tom smyslu, jakým způsobem klienta informovat, jak nakládat s pokyny klienta, jak je zpracovávat apod., MiFID dále upravuje informační povinnosti obchodníka s cennými papíry vůči České národní bance.

\section{Ochrana investorů a odpovědnost společnosti}

Směrnice o trzích finančních nástrojů má v Evropské unii zajistit zvýšení ochrany investorů. Zvýšená transparentnost týkající se stanovení cen a obchodních informací by měla vést k lepšímu propojení finančních trhů v Evropské unii.

Všichni obchodníci mají povinnost před poskytnutím jakékoliv investiční služby svým zákazníkům podle zákona č. 256/2007 Sb. o podnikání na kapitálovém trhu, klienta (zákazníka) zařadit do jedné z kategorií neprofesionální (retailový) zákazník, zákazník s nejvyšší ochranou, profesionální zákazník nebo způsobilá protistrana.

Cílem členění do kategorií je chránit klienty s menšími investičními znalostmi a zkušenostmi. Nejvyšší stupeň klientské ochrany se vztahuje na neprofesionální zákazníky/investory. Zákazník této kategorie získává nejširší rozsah relevantních informací o investičních službách a produktech. Zákazník této kategorie je zároveň před využitím konkrétní investiční služby upozorněn na možná rizika spojená s její realizací. Většina klientů, zejména fyzických osob je proto zařazena do kategorie neprofesionální zákazník. Do kategorie profesionální zákazník a způsobilá protistrana se řadí především banky, obchodníci s cennými papíry, investiční společnosti, pojišt'ovny, penzijní fondy, aj. a výjimečně i fyzické osoby. Předpokládá se, že tito zákazníci jsou schopni dělat vlastní investiční rozhodnutí, odhadnout potenciální rizika a nepotřebují tak vysoký stupeň klientské ochrany jako drobní (neprofesionální) zákazníci s omezeným přístupem $\mathrm{k}$ potřebným informacím při využití konkrétní investiční služby. Pro obchodníka jsou zcela noví klienti a stávající klienti z oblasti investičních produktů klasifikování v souladu s př́íslušnými zákony jako retailoví klienti (kategorizace MiFID klienti z řad obyvatelstva) a proto je jim umožněna plná ochrana všech př́slušných předpisů. Obchodník musí klientovi jasně vysvětlit pravidla, kterými se řídí jejich klasifikace, jejich právo žádat o změnu klasifikace za daných okolností a potenciální omezení ochrany, které v důsledku toho nastanou. Potenciální nebo stávající klient je v souladu s př́íslušnými zákony oprávněn žádat o povýšení do kategorie podnikových klientů, pokud však jsou splněna jistá kritéria, ale takový požadavek však nemusí být obchodníkem s cennými papíry dle př́islušných zákonů přijat.

Pro každý distribuční kanál (banka, investiční společnost, investiční poradce nebo burzy) je orgán dohledu (např. vedoucí společnosti, ředitel, management atd.) zodpovědný za zajištění toho, že obchodní proces týkající se jejich konkrétního distribučního kanálu je dodržen. Konečná odpovědnost za tento dokument většinou náleží manažerovi investičních produkti̊, který je podřízen řediteli nebo vedoucímu pobočky. Klientovi by měli investiční služby poskytovat pouze řádně vyškolení a certifikovaní obchodníci. Obchodník musí důkladně rozumět investičním produktům a s nimi spojeným rizikům a prrínosům. Neškolení nebo 
necertifikovaní pracovníci by neměli diskutovat ani nabízet nebo jinak se angažovat $\mathrm{v}$ tématech vztahujících se $\mathrm{k}$ investicím. Za poskytování školení $\mathrm{v}$ oblasti investičních produktů a za řízení (správu) investičních certifikací obchodníků většinou odpovídá management investičních produktů dané společnosti.

Každý obchodník vždy musí klienta před jakýmkoliv vlastním vydáním, výměnou nebo odkoupením investičních produktů řádně informovat o podstatě a rizicích, která jsou spojena s jednotlivými investičními produkty a $\mathrm{v}$ obecné rovině jsou povinni zveřejnit minimální množství informací, jakými jsou:

- investiční produkty podléhají investičním rizikům, včetně možné ztráty investované částky,

- investiční produkty mohou podléhat kolísání měny nebo deviz,

- investiční nástroj klienta, svěřený obchodníkovi s cennými papíry za účelem poskytnutí investiční služby je pojištěn u Garančního fondu obchodníků s cennými papíry,

- minulý výnos není zárukou budoucího výnosu, ceny se mohou zvyšovat nebo snižovat,

- dále obchodníci s cennými papíry musí klienty informovat o podstatě, charakteristikách a rizicích spojených s jednotlivými investičními produkty, které podléhají vydávání investičních cenných papírů dotčenému klientovi, a proto obchodník musí učinit následující:

- informovat klienty o jakýchkoliv specifických informacích, jenž diktují jednotlivé burzovní prospekty/stanovy nebo jiné zakládající dokumenty př́slušných investičních produktů, výroční zprávy a pololetní zprávy (,zakládající dokumenty“) a poskytnout aktuální přehled údajů o dotčených produktech, pokud jsou pro tyto účely schváleny $\mathrm{k}$ distribuci,

- informovat klienty o poplatcích, výhodách a nákladech, jež souvisejí s jednotlivými investičními produkty a také představit klientům aktualizovaný soupis poplatků.

Obchodníci s cennými papíry musí hlásit příslušnému orgánu všechny uskutečněné obchody a to proto, aby se zajistilo, že řádně vykonávají svou činnost. Obchodníci sdělují podrobnosti o svých transakcích pouze místnímu kontrolnímu úřadu. Nemají vykazovací povinnost vůči řadě kontrolních orgánů nebo burz v Evropské unii. Odpovědnost za výměnu informací s ostatními regulačními či kontrolními úřady v ostatních členských státech EU nese př́islušný domácí orgán na trhu, popř. domácí kontrolní orgán. Ustanovení směrnice MiFID definuje typy informací, které je nutné sdělit příslušnému domácímu orgánu. Informace poskytnuté domácímu orgánu by měly být postačující i pro ostatní státní regulační úřady v EU.

\section{Proces profilování zákazníka}

Směrnice MiFID zavedla nová pravidla pro provádění pokynů zákazníků. Obchodníci s cennými papíry jsou především vázáni povinností připravit a dodržovat pravidla pro provádění pokynů zákazníků za nejlepších podmínek a tato pravidla poskytnout zákazníkům pro jejich plnou informovanost. Každý obchodník dostál této povinnosti vytvořením a zavedením politiky pro provádění pokynů za nejlepších podmínek na základě různých kritérií, která směřují k dosažení co možná nejlepšího výsledku pro zákazníky. Pravidla provádění pokynů se liší podle typu smlouvy a provádění pokynů se aplikuje i u klientů, kteří uzavřeli smlouvy před zavedením změn podle pravidel směrnice MiFID. 
Každý obchodník musí klientovi poskytnout standardní investiční dokumentaci ještě před uzavřením obchodu tak, aby se s ní klient mohl důkladně seznámit. Obchodník jako poskytovatel investičních služeb je podle směrnice MiFID povinen získat od klienta informace $\mathrm{v}$ rozsahu nezbytném $\mathrm{k}$ tomu, aby porozuměl zásadním skutečnostem o klientovi a aby nabyl přesvědčení, že investiční služba, nástroj či obchod jsou pro zákazníka přiměřené.

U prodeje investic realizovaných na základě poradenství musí obchodník klientovi vysvětlit účel profilování, obchodník musí obdržet od klienta dostatečné množství údajů s cílem zajistit, že formulář profilování (viz kapitola 3.1) bude dokončen a že bude jasně označovat oblasti potřeb a priorit klienta. Obchodník by měl klienta vyzvat k poskytnutí veškerých požadovaných informací, aby mohl dát vhodné doporučení. Tam, kde klient odmítne podat jakékoliv informace, musí mu být sděleno, že jeho rozhodnutí znamená, že mu nelze poskytnout žádné poradenství a že nebude mít výhodu z hodnocení testu vhodnosti a bude též varován o omezeních odpovědnosti. Proces profilování s vysvětlením jeho účelu (stanovení kapacity klientova rizika, postoj k riziku a znalosti a zkušenosti v oblasti investic) postupuje každý klient, který má zájem o investiční produkty. Pokud však klient dostatečně nechápe, že tento účel je součásti povinné informační povinnosti vůči klientovi, obchodník musí zákazníka jasně informovat o tom, že pokud jsou poskytnuty veškeré informace požadované pro test vhodnosti (viz kapitola 3.2) nebo přiměřenosti (viz kapitola 3.3) tak, jak jsou obsaženy ve formuláři profilování, tak má klient nárok na to, aby obdržel investiční poradenství $\mathrm{k}$ produktům $\mathrm{v}$ rozsahu odpovídajícím jeho profilu. V opačném případě mohou být takovému klientovi poskytovány pouze neporadenské služby (proces prodeje „bez poradenství“ a transakce ,pouze v provedení“, viz kapitola 4). Toto musí být jasně vysvětleno každému klientovi dříve, než je vůbec jakákoli investiční transakce uskutečněna.

Hlavním pilířem veškerého investičního poradenství je tedy profilování. Účelem procesu profilování je stanovení specifičnosti rizik (postoj $\mathrm{k}$ riziku), finanční schopnost zacházet $\mathrm{s}$ rizikovou angažovaností (kapacita rizika) a znalosti a zkušenosti z různých typů investičních produktů. Tyto informace jsou využity obchodníkem $\mathrm{k}$ určení nejpřiměřenější investiční strategie pro zákazníka.

\subsection{Formulář profilování klienta}

V procesu profilování je používán formulář profilování neboli formulář investičního profilu klienta, jenž je dotazník určený k tomu, aby pomohl určit klíčové prvky, které jsou důležité pro provádění investičního rozhodnutí klienta. Účelem procesu profilování klienta je stanovení specifičnosti rizik (postoj klienta k riziku), současný finanční cíl a časový horizont klienta. Definováním přijatelné úrovně klientova rizika se obchodník spolu s klientem „přibližuje“ jeho očekávání ohledně výnosů z jeho investice. Definování rizika a časový horizont jsou zákazníkovi vodítkem směrem k jeho investičnímu rozhodnutí. Nicméně konečné rozhodnutí ohledně toho, která investice odpovídá zákazníkovým potřebám, je vždy plně založena na klientově výhradním rozhodnutí.

Vytipování klientových potřeb a cílů je dokumentováno ve formuláři profilování, příloha č. 1 test vhodnosti-bod I. Tolerance ve vztahu k rizikům a test znalosti a zkušenosti. Na základě profilování je získáno skóre zohledňující rizikovou kapacitu klienta, postoj k riziku a znalosti a zkušenosti z různých druhů investičních produktů. Pokud nebude zodpovězena jedna nebo více otázek nebo klient odmítne být profilován, přesto musí obchodník požadovat, aby klient podepsal omezení odpovědnosti a následně pak budou klientovy transakce klasifikovány jako neporadenské služby. Formulář profilování musí být vyplněn u každého klienta a musí být 
podepsán jak obchodníkem, tak klientem. Ve formuláři profilování jsou postačující požadavky na testování vhodnosti a přiměřenosti (viz kapitola 3.2 a 3.3). Obchodník rovněž zákazníka upozorňuje, že s veškerými získanými informacemi se zachází podle pravidel pro zachování důvěrnosti informací a že klient má právo odmítnout odpovědět na formulár̆ profilování.

\subsection{Test znalosti a zkušenosti neboli test přiměřenosti}

Test znalosti a zkušenosti (součást formuláře profilování se nazývá také testem přiměřenosti) musí obchodník vyplnit s klientem během diskuse a používá se pro všechny poradenské diskuse a komplexní produkty. Toto hodnocení zahrnuje otázky týkající se předchozí historie klientovy koupě investičních produktů, pochopení povahy těchto produktů a rizik spojených $\mathrm{s}$ investicemi, a navíc i klientovy úrovně vzdělání a oblastí odborné činnosti. Tento test má ve spojení s jinými informacemi shromážděnými ve formuláři profilování za cíl poskytnout obchodníkovi dostatečné informace pro provedení hodnocení vhodnosti produktu a konkrétně $\mathrm{v}$ případě komplexních produktů i posouzení přiměřenosti obchodu. Klientovy odpovědi $\mathrm{v}$ rámci testu znalosti a zkušenosti představují základ, na němž bude transakce pokračovat. Pokud klientovy odpovědi na dotazy týkající se znalostí a zkušeností naznačují, že nerozumí rizikům a povaze komplexních investičních produktů, nebude obchodník zákazníka povzbuzovat k zakoupení takovýchto produktů, pokud o ně zákazník sám neprojeví aktivní zájem. Z informací shromážděných prostřednictvím procesu zjišt’ování skutečností, musí být obchodník schopen prokázat, že doporučení vyhovuje cílům klienta, že klient si může dovolit nést jakákoliv rizika spojená s investicí a že klient je na základě svých znalostí a zkušeností schopen rozumět rizikům spojených s investiční transakcí.

Test přiměřenosti je povinný pro komplexní produkty (strukturované dluhopisy), musí být vyplněn spolu s testem vhodnosti, jinak nelze nabídnout klientům žádné poradenské služby v souvislosti s komplexními produkty (strukturované dluhopisy) a takovíto klienti musí být klasifikování pro neporadenské služby. Navíc je tato část zaměřena na rozšîrený rozsah znalostí a zkušeností s ohledem na čtyři kategorie investičních produktů a představuje rozvinutý test vhodnosti.

Test znalosti a zkušenosti tedy hodnotí pochopení nebo zkušenosti zákazníka s investičními produkty do čtyř úrovní:

1. úroveň NEKOMPLEXNÍ - makléřské produkty, podílové fondy a penzijní fondy,

2. úroveň KOMPLEXNÍ - kapitálem chráněné strukturované produkty (dlouhodobé a krátkodobé držení),

3. úroveň KOMPLEXNÍ - částečně chráněné a nechráněné strukturované dluhopisy,

4. úroveň KOMPLEXNÍ - dluhové produkty a zajištovací (hedgeové) fondy.

V př́padech, kdy klient prohlásí hned od začátku, že si přeje provést transakci „pouze $\mathrm{v}$ provedení“ (viz kapitola 4) a nevyžaduje od obchodníka žádné poradenství a odmítá vyplnit formulár profilování, potřebuje obchodník přesto určit prriměřenost produktu použitím testu přměřenosti. Tam, kde vhodnost nelze zhodnotit vzhledem $\mathrm{k}$ nedostatečným informacím nebo kde klient odmítne nabízené poradenství, je nutné ke komplexní povaze těchto produktů se řídit postupy transakce ,pouze $\mathrm{v}$ provedení “ a to vzhledem $\mathrm{k}$ odpovědnosti na straně obchodníka. V těchto př́ípadech lze použít izolovaně test znalosti a zkušenosti (pouze část přiměřenost, která je součástí formuláře profilování) a stanoví se, zda produkt je pro daného klienta vhodný nebo ne. $\mathrm{V}$ každém jednotlivém případě musí obchodníci rozumět rozdílům mezi přiměřeností a vhodností, tzn. kdy a za jakých podmínek je poskytováno investiční 
poradenství. Pokud klient požádá obchodníka, aby transakci realizoval navzdory tomu, že obdrží ústní varování, obchodník musí, coby další úroveň opatrnosti zvážit, zda by koupě produktu byla v „nejlepším zájmu“ klienta. Pravidlo „nejlepšího zájmu“ zahrnuje skutečnost, že obchodník jedná čestně, spravedlivě a profesionálně v souladu s nejlepšími zájmy svých klientů. Např́ḱlad pokud obchodník pozná, že si klient nikdy předtím nekoupil strukturovaný produkt a nerozumí vůbec investičním produktům, neměl by s transakcí pokračovat.

\subsection{Test vhodnosti}

Test vhodnosti začíná identifikací klienta včetně jeho daňové příslušnosti a mírou rizika, kterou je schopen podstoupit. Jestliže klient poskytne veškeré požadované odpovědi, obchodník má dostatek informací k tomu, aby stanovil klientův investiční profil a tento klient je oprávněn získat nárok na poradenství o investičních produktech v rozsahu odpovídajícím jeho profilu. Pokud nebudou ve formuláři profilování uvedeny veškeré informace, budou klientovy transakce klasifikovány jako „pouze v provedení“ (neporadenské služby). Klientům, kterým jsou doporučeny pouze vhodné produkty, které odpovídají jejich rizikovému profilu, klient investuje dle doporučení, tak tyto transakce budou považovány za „prodeje s poradenstvím“. Test vhodnosti se provádí s cílem stanovit, jaký typ investičních služeb pro klienta bude nejvhodnější. Obchodník pokládá klientovi otázky z oblasti jeho investičních cílů, finanční situace a znalostí a zkušeností. Při hodnocení vhodnosti jsou zohledňována specifická rizika, kapacita a znalosti a zkušenosti. Bude-li to relevantní, mohou být klientům rovněž nabízeny investiční produkty, které jsou méně agresivní, než je jejich rizikový profil. Vhodnost lze určit na základě informací shromážděných prostřednictvím vyplnění formuláře profilování. Hodnocení rizika samotné však není jedinou úvahou, na jejímž základě se stanoví vhodnost, je třeba zohlednit specifické potřeby klienta. Obchodník nesmí nabídnout klientům produkty, u kterých je schopen dle procesu prodeje investic předem stanovit, že jsou pro zákazníka nevhodné, anebo nepřiměřené. Například strukturovaný dluhopis s hodnocením rizika odpovídajícím klientovu profilu může být nevhodný, např̀ pokud má pětiletou splatnost a klient má tř́letý horizont.

\section{Přehled investičních transakcí}

Směrnice MiFID poskytuje pokyny ohledně zacházení s investičními transakcemi uzavřenými v zastoupení klientů a tyto transakce s klienty by měly spadat do jedné ze dvou kategorií a čtyř podkategorií:

- s poradenstvím,

- bez poradenství,

- transakce navzdory poradenství,

- transakce spočívající v pouhém provedení

a výhradně pro komplexní produkty, kde byly poskytnuty pouze informace týkající se znalostí a zkušeností klienta,

- transakce spočívající v pouhém provedení,

- nepřiměřená transakce s komplexním produktem spočívající v pouhém provedení.

\section{PROCES PRODEJE S PORADENSTVÍM}

Pokud obchodník dokončil $\mathrm{s}$ klientem test vhodnosti a přiměřenosti a klient příjme doporučení, může se pokračovat v investičních transakcích a tudíž budou tyto transakce kvalifikovány jako prodeje s poradenstvím. Každý z produktů má své hodnocení, které je doporučeno do př́slušné kategorie rizikového profilu. Obchodník může v souladu s pokyny klienta doporučit klientovi jediný produkt nebo skupinu produktů (na základě měny, třídy 
majetku, atd.), ale vždy až po výši odpovídající jeho profilu a takové produkty musí být pro klienta vhodné a přiměřené.

Proces prodejů s poradenstvím se musí držet níže uvedeného sledu kroků, které byly formulovány s cílem zajistit vyhovující prodej:

1. řádně dokončený proces profilování, kde klient poskytuje veškeré požadované informace,

2. prezentace investičních produktů podle profilování,

3. stanovení vhodnosti (jak z podnětu klienta, tak z podnětu obchodníka),

4. dokončení prodeje a s tím spojená služba pro prodej podle procesu prodeje investic.

Pokud nebudou výše uvedené podmínky zcela splněny, obchodníci nesmějí charakterizovat nebo jinak prezentovat investiční služby jako „,prodeje s poradenstvím“. Veškeré koupě a jiné zacházení s investičními produkty nad odpovídající profil zákazníka, jsou považovány za „neporadenské“.

Obchodník je povinen tedy uskutečňovat pokyny klientů jen za nejlepších podmínek a to podle kritérií a faktorů, které jsou upraveny ve smluvních podmínkách. Obchodník rovněž informuje klienta o pravidlech pro podávání pokynů a jejich změně. Dále upozorňuje klienta, že pravidla pro provádění pokynů se nevztahují na investiční nástroje, u kterých klient nepodává pokyn, ale realizace klientova obchodu závisí vždy na uzavření dílčích obchodů $\mathrm{s}$ obchodníkem (např. OTC obchody s finančními deriváty). Rozhodujícími kritérii pro provádění pokynů za nejvýhodnějších podmínek jsou cena investičního nástroje, která je předmětem obchodu, celkový objem poplatků vyúčtovaných klientovi, rychlost s jakou lze pokyn provést, pravděpodobnost provedení pokynu, objem investičních nástrojů, které jsou předmětem obchodu, podmínky a způsob vypořádání obchodu a typ pokynu. Obchodník provádí pokyny za nejlepších podmínek pro klienta, nestanoví-li klient jiné podmínky pro provedení pokynu.

\section{PROCES PRODEJE BEZ PORADENSTVÍ}

Je proces, kdy klient si nepřeje se držet doporučení, které mu dal obchodník na základě jeho identifikovaného rizikového profilu stanoveného $\mathrm{v}$ souladu s procesem prodeje investic. Neexistuje-li žádná změna $\mathrm{v}$ okolnostech klienta a skutečnostech ovlivňujících informace obsažené ve formuláŕi profilování, nebo pokud si jej klient odmítá znovu projít a má pocit, že jeho rizikový profil je správný, přesto je možné dát pokyny k transakci. Obchodník může pokračovat, ale bez zakomponování jakýchkoliv investičně poradenských služeb, tzn. obchodník s cennými papíry nedá žádná osobní doporučení s ohledem na investiční produkty. Klient musí být vždy s ohledem na daný konkrétní produkt zřetelně varován obchodníkem, že se přechází na transakci typu „,bez poradenství“ neboli tzv. „execution only“. Obchodník tedy provede pouze transakci, která mu byla zadána $\mathrm{z}$ iniciativy klienta a nijak neposuzuje vhodnost této transakce u klienta.

\section{TRANSAKCE POUZE V PROVEDENÍ}

$\mathrm{V}$ případě, že klient odmítne držet se závěrů $\mathrm{v}$ návaznosti na proces profilování nebo nechce být profilován na základě procesu profilování nebo nesouhlasí s výsledky profilování a není ochoten odpovědět na některé nebo všechny otázky testu vhodnosti a obchodník nemá dostatečné informace, aby mohl stanovit klientův profil, tak takový klient bude profilován „,pouze v provedení“ (tzn. že mohou mu být poskytnuty pouze služby bez poradenství). U klienta se zájmem např. o komplexní produkty (strukturované dluhopisy) je povinný test přiměřenosti (test znalosti a zkušenosti) s cílem určit, zda je produkt u tohoto klienta 
přiměřený nebo nepřiměřený, a to i tehdy, pokud tento zákazník je profilován „pouze v provedení“. Pokud klient není ochoten odpovědět na některé otázky testu přiměřenosti, nemá obchodník dostatečné informace $\mathrm{k}$ tomu, aby zachytil přiměřenost produktu pro toho konkrétního klienta. Taková transakce bude klasifikována jako „pouze v provedení“ a „nepřiměřená“. Pokud obchodník zachytí veškeré požadované informace, jež mají za cíl stanovit přiměřenost produktu pro konkrétního klienta a produkt je v souladu s výsledky testu, bude takový produkt klasifikován jako přiměřený. Zákazník podpisem formuláře profilování a následně podáním př́kazu k obchodu stvrdí, že si je plně vědom rizik spojených s jeho volbou a že je za příslušná rizika výhradně odpovědný a že jakékoliv budoucí investiční koupě budou prováděny na základě transakce „pouze v provedení“.

\section{KLIENT NESOUHLASÍ S VYTVOŘENÝM RIZIKOVÝM PROFILEM}

Pokud by klient nesouhlasil $\mathrm{s}$ vytipovaným rizikovým profilem vyplývajícím $\mathrm{z}$ procesu profilování rizika, musí se obchodník držet následujících postupů:

1. Jaké okolnosti nebo skutečnosti relevantní vzhledem $\mathrm{k}$ procesu profilování rizika se změnily u klienta od doby, kdy byl naposledy vyplněn formulár profilování.

2. Obchodník nesmí klienta $\mathrm{v}$ žádné etapě procesu profilování rizika vybízet $\mathrm{k}$ alternativní reakci, která by mohla vést k zvýšení nebo snížení rizikového profilu. Jakékoliv změny rizikového profilu musí být výhradně v důsledku toho, že klient nezaujatě a je-li to relevantní, přehodnotí své odpovědi.

3. V př́padech, kdy se rizikový profil změní $\mathrm{v}$ důsledku toho, že klient přehodnotí své původní odpovědi a klient souhlasí s následným profilem, může transakce (pokud odpovídá revidovanému rizikovému profilu) pokračovat na základě poradenství dle procesu prodeje investic.

4. V př́ípadě, že zákazník dosud nesouhlasí, obchodník bude pokračovat transakci „pouze provedení“.

\section{ODMÍTNUTÍ BÝT PROFILOVÁN}

Klientovi je vždy předložena poradenská služba a nabídka profilování, nicméně pro vlastní důvody klienta, si nemusí klient přát vyplnit profilovací dokumentaci. Formulář profilování musí být vždy podepsán a datován obchodníkem a klientem. Všichni klienti „,neochotní dát se profilovat“"jsou klasifikováni ,pouze v provedení“.

\subsection{Klasifikace investičních transakcí a produktů}

Nedílnou součástí nových požadavků MiFID, které ovlivňují změny procesu prodeje investic, je pojetí rozdělení investičních produktů na „komplexní“ a „nekomplexní“ produkty. V rámci současného produktového rozpětí jsou nástroje peněžního trhu, dluhopisy a akcie přijaté k obchodování na regulovaném trhu a cenné papíry fondů kolektivního investování klasifikovány jako nekomplexní produkty. Strukturované dluhopisy, opce, futures, swapy, vyměnitelné dluhopisy nebo opční listy jsou klasifikovány jako komplexní produkty.

Komplexní produkty jsou doporučeny pouze tehdy (tzn. v závislosti na poradenských prodejích), pokud jsou vhodné a přiměřené $\mathrm{v}$ souladu $\mathrm{s}$ procesem prodeje investic. To znamená, že splňují klientovy investiční cíle, odpovídají jeho finanční situaci, specifickým rizikům a časovým rámcům včetně znalostí a zkušeností investičních služeb a produktů. Od klientů se požaduje, aby měli za účelem koupě komplexního produktu rizikový profil a aby se jejich úroveň znalosti a zkušenosti rovnala dané úrovni nebo byla vyšší (tj. minimální úroveň u kapitálově chráněných komplexních produkti̊), přičemž jim budou nabízeny pouze ty 
produkty, které odpovídají jejich rizikovému profilu, anebo produkty nižší (tzn. konzervativnější). Pokud si klient preje koupit komplexní produkt nad rizikový profil klienta, musí být informován, že obchod bude považován za „,nevhodný“, tzn. mimo rozsah „, poradenstvím“ a bude proto zpracováván jako „bez poradenství“.

Komplexní produkty jako např. strukturované dluhopisy rozlišujeme dle jejich nabídky na soukromé umístění a veřejnou emisi. Prostřednictvím soukromého umístění nejsou strukturované dluhopisy registrovány v České republice, pokud nebyly oznámeny České národní bance pro účely veřejné a z tohoto důvodu nemohou být nabízeny veřejnosti, pokud nejsou splněny všechny podmínky. Požadavek soukromého umístění stanoví sadu požadavků týkajících se minimálních částek nebo počtu investorů. Strukturované dluhopisy distribuované prostřednictvím veřejné emise jsou řádně oznámeny České národní bance pro účely veřejné emise v rámci České republiky. Když je strukturovaný dluhopis řádně oznámen, neexistuje žádné obecné omezení co do částky nebo počtu klientů.

\section{Změny před vlastní investicí}

Směrnice MiFID je považována za skok v regulaci finančního trhu v Evropské unii a nejvýznamnější změny novely se oproti původnímu znění zákona dotkly hlavně oddílu Jednání obchodníka s cennými papíry se zákazníky. Směrnice MiFID přinesla řadu změn jako kategorizaci zákazníků a jak ji provádět. Problémy s kategorizací zákazníků mohou nastat až tehdy, když je s drobným zákazníkem zacházeno jako s profesionálem, protože u těchto dvou kategorií se výrazně liší míra ochrany, rozsah poskytovaných informací a prováděné testy. Oddělení pro zajištění souladu s touto směrnicí musí zajistit, aby přidělená klasifikace byla správná a obchodník s cennými papíry jednal s každým zákazníkem v souladu s jeho zařazením. Směrnice udává také podrobná pravidla při hodnocení investičních služeb $\mathrm{a}$ investičních nástrojů vhodných pro klienta $\mathrm{v}$ dané kategorii. $\mathrm{V}$ této souvislosti klade MiFID na obchodníka vyšší požadavky při zjištování informací od zákazníků - detailně popisuje jakým způsobem klienta informovat, jak nakládat s pokyny zákazníka, jak je zpracovávat, apod.. Vyžadování informací od klienta je spojeno s poskytováním investiční služby obhospodařování majetku zákazníka, je-li jeho součástí investiční nástroj, dále volné úvahy v rámci smluvního ujednání a služby investičního poradenství týkajících se investičních nástrojů. Obchodník s cennými papíry je povinen získat od zákazníka nezbytné informace jako odborné znalosti a zkušenosti v oblasti investic, finanční zázemí a investiční cíle, které stanovuje prováděcí právní předpis.

Směrnice přináší nové možnosti jako větší likviditu, požadavky na kapitál, nižší marže a transakční náklady. Požadavky směrnice jdou však v některých případech do příliš velkých detailů a ve srovnání s tehdejším postupem prodeje a nabídkou investičních produktů jsou mnohem náročnější na běžný provoz a evidenci. Náklady spojené s MiFIDem tak nejsou jednorázové, spojené se zavedením nových postupů, nýbrž představují trvale zvýšenou nákladovou položku. Růst nákladů na straně obchodníků může být způsoben náklady na informační technologie, čímž se však mohou zvýšit poplatky pro investory, nikoli snížit. Lze konstatovat, že směrnice je vnímána jak pozitivně (částečně brání zneužívání finančního trhu), tak i negativně (přeregulovanost, která více problémů způsobuje, než řeší; vyšší náklady pro všechny zúčastněné a nejistota z budoucího vývoje).

Výhodou většiny společností na českém kapitálovém trhu, jenž jsou součástí nadnárodních finančních institucí je, že mohou centrálně využívat vyvíjených postupů i produktů. Díky MiFIDu by měli mít obchodníci s cennými papíry snadnější přístup k zákazníkům v České 
republice a naopak čeští občané by měli mít snadnější přístup k finančním produktům nabízeným v rámci celé EU. Výsledkem je větší konkurence, a tím i lepší služby pro české investory.

Hlavní dopady směrnice MiFID jsou na :

a) investiční produkty - konkurence posílí investice do nových, inovovaných produktů $\mathrm{s}$ vyšší marží, což povede k redukci tradičních produktů,

b) provozní infrastrukturu - větší objem transakcí klade větší nároky na obslužný personál, zvýšení nároků na zpracování dat a nová pravidla obchodování,

c) zákazníky a distribuci - vytvoření nových a mezinárodních příležitostí, rozšiřování klientely, přehodnocení stávajícího distribučního modelu,

d) trhy - větší počet prodejních míst,

e) outsourcing - harmonizaci legislativy a jednotné tržní infrastruktury, včetně zadávání provozních úkolů externím subjektům,

f) investiční poradenství - nelze vykonávat jako živnost, investiční zprostředkovatelé a jeho vázaní zástupci mohou tuto činnost vykonávat pouze na základě zápisu do př́islušného registru vedeného Českou národní bankou.

Lze konstatovat, že sumarizací všech finančních instrumentů a služeb regulovaných směrnicí o trzích finančních instrumentů, se směrnice vztahuje na většinu účastníků trhu, kteří obchodují nebo poskytují služby zákazníkům. Řadě finančních institucí může přinést směrnice MiFID v dlouhodobém výhledu prospěch a to pokud ji úspěšně implementují (je to př́ležitost, která se dává a minimalizuje náklady, které s sebou nese).

\section{Závěr}

Základem uvedené směrnice je zásadně nové chápání investora a jeho vztahu k obchodníkovi s cennými papíry. Cílem směrnice je tedy sladit ochranu investora v celé Evropské unii a účelem pravidel jednání ve vztahu k zákazníkům je vymezit, kam až sahá ochrana zákazníka v rámci EU. Směrnice MiFID by měla regulatorním orgánům a investorům poskytnout vodítko pro rozpoznání a potrestání neefektivních služeb a nesprávného chování obchodníků $\mathrm{s}$ cennými papíry. MiFID definuje základní požadavky na poskytování informací a povinností obchodníků s cennými papíry vůči klientům při správě cizího majetku. Řada konkrétních pravidel MiFID se týká zejména drobných zákazníků, protože ti zpravidla mají v oblasti finančních trhů a produktů méně znalostí a zkušeností.

Směrnice MiFID se dotkla všech klientů, kteří využívají jakýkoli investiční nástroj, tj. investiční cenné papíry (zejména akcie a dluhopisy), cenné papíry kolektivního investování, nástroje peněžního trhu a všechny druhy derivátů (včetně strukturovaných produktů). Každý klient je podle kritérií stanovených zákonem nově zařazen do jedné ze tři kategorií (neprofesionální zákazník, profesionální zákazník, způsobilá protistrana). Na každou kategorii se vztahuje rozsah informací, které jsou poskytovatelé investičních služeb investorům povinni poskytnout tak, aby byl investiční proces pro klienty co nejsrozumitelnější. Tato nová úprava má zlepšit ochranu investorů na kapitálových trzích. Nejvíce chráněni jsou drobní investoři, kteří mají malé znalosti a zkušenosti v oblasti investování na rozdíl od profesionálních zákazníků, kde je míra ochrany nižší (patří zde banky, pojišt’ovny, investiční společnosti, penzijní a investiční fondy).

Příspěvek lze považovat za postup obchodníka s cennými papíry při kontaktu s klientem, kdy obchodník na začátku obchodního vztahu určuje zařazení klienta a následně provádí investiční 
poradenství s tím, že obchodník s cennými papíry rozumí specifickým potřebám a situaci klienta a zjišt'uje, zda investiční poradenství poskytne anebo ne. Pro obchodníky s cennými papíry vždy platí, že jakákoliv transakce musí být v nejlepším zájmu zákazníka. Pokud ne, neměl by obchodník takovouto transakci akceptovat. Obchodník je také povinen poskytovat investorům přiměřené zprávy o provedených pokynech. Pokud obhospodařuje i zákaznický majetek, měl by rovněž informovat o stavu peněžních prostředků a investičních nástrojích $\mathrm{v}$ investorově portfoliu. Všechny změny jsou navrženy tak, aby zajistily přiměřenou ochranu při investování do investičních produktů.

\section{Literatura}

[1] Akcie a investice. Zdroj: Fio banka, cit 27. únor 2011, http://www.fio.cz/akcieinvestice/chci-spravu-portfolia.

[2] Citibank. Zdroj: Citibank Europe plc, organizační složka, cit 2. července 2012, http://www.citibank.cz/czech/gcb/personal_banking/czech/investment/investice.htm?ici $\mathrm{d}=$ LINK-INV-HP-TOPMENU.

[3] European commission. Zdroj: European commission, cit 27. únor 2011, http://ec.europa.eu/internal_market/securities/isd/index_en.htm.

[4] Informace o směrnici MiFID. Zdroj: Volksbank, cit 27. únor 2011, http://www.volksbank.cz/vb/jnp/cz/podnikatele/investovani/cz-podnikatele-ivestovanimifid.html.

[5] Informace pro klienty dle MiFID. Zdroj: ČSOB, cit 27. únor 2011, http://www.csob.cz/cz/Csob/O-CSOB/Povinne-informace/Stranky/InformaceMIFID.aspx.

[6] Licencovaní obchodníci s cennými papíry. Zdroj: Finance, cit 27. únor 2011, http://www.finance.cz/kapitalovy-trh/seznamy/obchodnici/.

[7] MiFID. Zdroj: Česká spořitelna, a.s., cit 27. únor 2011, http://www.csas.cz/banka/content/inet/internet/cs/sc_2863.xml.

[8] MiFID. Zdroj: GE Money bank, cit 27. únor 2011, http://www.gemoney.cz/ge/cz/1/investovani/mifid.

[9] MiFID: Prüvodce spotřebitele. Zdroj: ČNB, cit 27. únor 2011, http://www.cnb.cz/miranda2/export/sites/www.cnb.cz/cs/spotrebitel/ochrana_spotrebitel e/MiFID_CZ.pdf.

[10] Pravidla pro provádění pokynů. Zdroj: Komerční banka, a.s., cit 27. únor 2011, http://www.kb.cz/cs/informace-k-mifid/pravidla-pro-provadeni-pokynu/index.shtml.

[11] Působnost a definice. Zdroj: Ministerstvo financí ČR, cit 27. únor 2011, $\mathrm{http} / / / \mathrm{www} . \mathrm{mfcr} . c z / \mathrm{cps} / \mathrm{rde} / \mathrm{xbcr} / \mathrm{mfcr} /$ Konzultacni_material_MF-MiFID1stpd2006_C_pdf.pdf.

[12] Směrnice o trzích finančních nástrojů (MiFID - nová pravidla pro kapitálový trh. Zdroj: Ministerstvo financí ČR, cit 27. únor 2011, http://www.mfcr.cz/cps/rde/xchg/mfcr/xsl/kap_trh_mifid_28136.html?year=PRESENT.

[13] Take a balanced approached. Zdroj: Deloitte Česká republika, cit. 27. únor 2011, http://www.deloitte.com/assets/Dcom-

CzechRepublic/Local\%20Assets/Documents/cz(en)_mifid_balance_160407.pdf.

[14] Zákon č. 256/2004 Sb., o podnikání na kapitálovém trhu, Zdroj: Ministerstvo financí České republiky, cit. 27. únor 2011 http://www.mfcr.cz/cps/rde/xbcr/mfcr/ZPKT_uplne_zneni2_pdf.pdf. 
JEL G21, G24

\section{Ing. Lucie Meixnerová}

Ústav doktorských studií, kombinovaná forma studia

Obchodně podnikatelská fakulta v Karviné, Slezská univerzita v Opavě

Zaměstnavatel: Citibank Europe plc, organizační složka, Nádražní 11, 700 39, Ostrava

Adresa pro zasílání korespondence: Maková 1374/10, 725 25, Ostrava - Polanka nad Odrou

luciemeixnerova@seznam.cz 
Př́iloha č. 1 Profilační dotazník klienta

\section{ČAST 2. PROFILAČNI DOTAZNIK}

\section{TOLERANCE VE VZTAHU K RIZIKŮM}

V souvislosti s poskytovánim přislušných investičnich služeb, resp. obchodû s investičnimi nảstroji je Citibank Europe plc (dále jen ..Citibank") povinna ziskat od Vás nezbytné

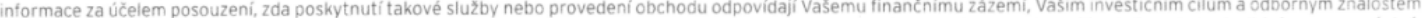

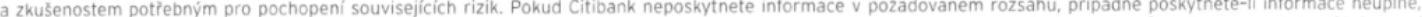

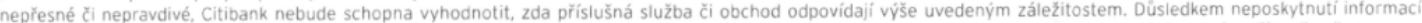

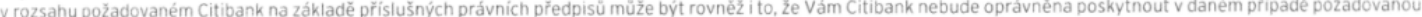
investični službu. Pokud Citibank neziská požadované informace nebo je vyhodnotí tak, že provedeni daného obchodu s investićnim nástrojem neodpovidá Vašim odbornỷm. znalostem nebo zkušenostem, Citibank nebude povinna pro Vás takový obchod provést. V této souvislosti Vám Citibank doporučuje, abyste poskyti/a veškeré požadované informace, které jsou ze strany Citibank považovány za nezbytné pro účely vyhodnoceni výše uvedených záležitostín

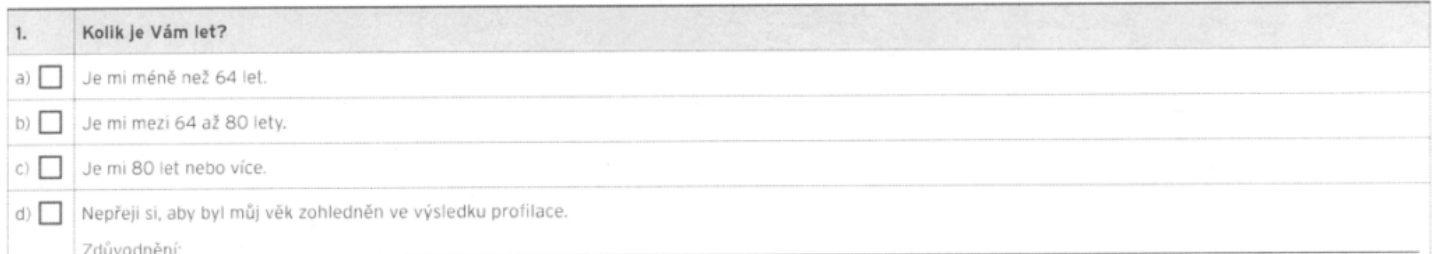

2. Jaký je celkový časový horizont, ve kterém uvažujete investovat prostřednictvím Vašich účtů u citibank?

a) Méné nez̃ 1 rok

b) $\square$ Mezi 1 a 3 roky.

$\square$ Vice než 3 roky.

d) $\square$ Casový horizont neize definovat.

e) $\square$ Odmítám na tuto otázku odpovědĕt.

3. Kolik měsícủ Vašich očekávaných výdajủ kryji Vaše celkové likvidni prostředky (např. zdroje na běžných účtech, spořicích účtech, termínovaných vkladech, fondy peněžniho trhu, jak je popsáno vy̌še v části „Zdroje príijmù")?

a) $\square$ Méně než 1 rok.

$\square$ Vice nez̃ 1 rok

$\square$ Odmitám na tuto otázku odpovědět

4. Jaké procento Vašich čistých finančnich aktiv (jak je popsáno výše v části „Obecné informace“) představuji investice prováděné prostřednictvím Vašich účtủ u Citibank? Vaše čistá finanční aktiva jsou definována jako součet (a) Vašich investičních aktiv (včetně běžného účtu, spořicího účtu a investic držených u Citibank nebo u třetich osob, avšak bez nemovitostí, které uživáte $k$ bydleni, a podniku/ủ, které vlastníte) minus (b) Vaše celkové závazky.

a) $\square$ Méně než čturtina

$\square$ Mezi čtvrtinou a polovinou.

$\square$ Vice neź polovina

d) $\square$ Odmitám na tuto otázku odpovẽdĕt

5. Do jaké míry očekáváte, že využijete aktiv na Vašich účtech u Citibank $k$ financováni Vašich výdajủ v následujicich pĕti letech?

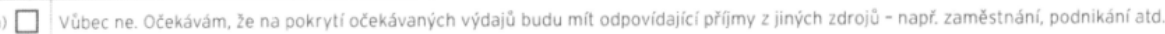

b) $\square$ Očekávám, že prostřednictvím tẽchto aktiv budu financovat malou đást očekávaných výdajư.

c) $\square$ Očekávám, že prostřednictvim těchto aktiv budu financovat vêtš̌inu očekávaných výdajũ.

d) $\square$ Odmitám na tuto otázku odpovědèt.

6. Předpokládáte, že $\mathrm{v}$ prìstích pĕti letech budete provádět dodatečné vklady do svých stávajicich celkových finančnich aktiv nebo naopak výbèry z nich?

a) $\square$ Očekávám, že budu provádět dodatečné vklady do svých finančnich aktiv.

p) $\square$ Není jisté, zdali budu provádět dodatečné vklady nebo výběry.

$\square$ Očekávám, że budu provádèt omezené výbèry (ménē nez̃ $25 \%$ současných finančnich aktiv).

4) OČekávám, że budu provádẻt značné výbèry (vice neż $25 \%$ současných finančnich aktiv).

e) Odmitám na tuto otázku odpovédét 
III. ZNALOSTI A ZKUŠENOSTI

\begin{tabular}{|c|c|c|c|c|c|}
\hline & $\begin{array}{l}\text { Máte znalosti } \\
\text { v této produktové ob- } \\
\text { lasti v dúsledku inves- } \\
\text { tičniho poradenstvi, } \\
\text { formálního vzděláni, } \\
\text { současného nebo bý- } \\
\text { valého povolání nebo } \\
\text { jiných skutečností?" }\end{array}$ & $\begin{array}{l}\text { Provedi/a jste } \\
\text { alespon̆ } \\
2 \text { transakce } \\
\text { v této produk- } \\
\text { tové oblasti za } \\
\text { poslednich } \\
24 \text { mésícú?"* }\end{array}$ & Zdroj znalosti & $\begin{array}{l}\text { Počet } \\
\text { transakcí }\end{array}$ & $\begin{array}{l}\text { Objem transakci } \\
(V C Z K)\end{array}$ \\
\hline & $\mathrm{Ano} / \mathrm{Ne}$ & $\mathrm{Ano} / \mathrm{Ne}$ & & & \\
\hline \multicolumn{6}{|l|}{ Nekomplexni } \\
\hline \multicolumn{6}{|l|}{ - Peněžni trhy a terminované vklady } \\
\hline \multicolumn{6}{|l|}{ - Podílové fondy } \\
\hline \multicolumn{6}{|l|}{$\begin{array}{l}\text { - Cenné papiry s pevným výnosem } \\
\text { (zejm. dluhopisy) }\end{array}$} \\
\hline \multicolumn{6}{|l|}{ - Nástroje devizového trhu (Forex) } \\
\hline \multicolumn{6}{|l|}{$\begin{array}{l}\text { - Hybridni cenné papíry } \\
\text { (např. preferenčni akcie) }\end{array}$} \\
\hline \multicolumn{6}{|l|}{ - Akcie } \\
\hline \multicolumn{6}{|l|}{ - Komodity } \\
\hline \multicolumn{6}{|l|}{ Komplexní } \\
\hline \multicolumn{6}{|l|}{ - Prémiové FX produkty } \\
\hline \multicolumn{6}{|l|}{ - Strukturované produkty } \\
\hline \multicolumn{6}{|l|}{ - Hedgeové fondy } \\
\hline \multicolumn{6}{|l|}{ - Private Equity } \\
\hline \multicolumn{6}{|l|}{ - Deriváty (futures, opce, swapy) } \\
\hline - Strukturované úvěrové produkty & & & & & \\
\hline
\end{tabular}

"V prípadě kladné odpovědi prosím vypiñte pole , Zdroj znalosti".

*. V príipadẽ kladné odpovédi prosím vyplñte pole „Počet transakci” a „Objem transakci”.

10. Vaše investični znalosti a zkušenosti lze nejlépe popsat takto:

$\square$ 1) Žádné: Mám velmi malé nebo nemám žádné znalosti investičních produktů

$\square$ 2) Omezené: Mám základni znalosti investičnich produktü

3) Středni: Mám dobré obecné znalosti investičnich produktủ a rozumím investičním produktûm a s nimi spojeným rizikưm

4) Rozsáhlé: Mám rozsáhlé znalosti investičnich produktû a rozumim investičním produktưm a s nimi spojeným rizikûm.

Zdroj: http://www.citibank.cz/czech/gcb/personal_banking/czech/static/pdf/inv_os_form.pdf 